
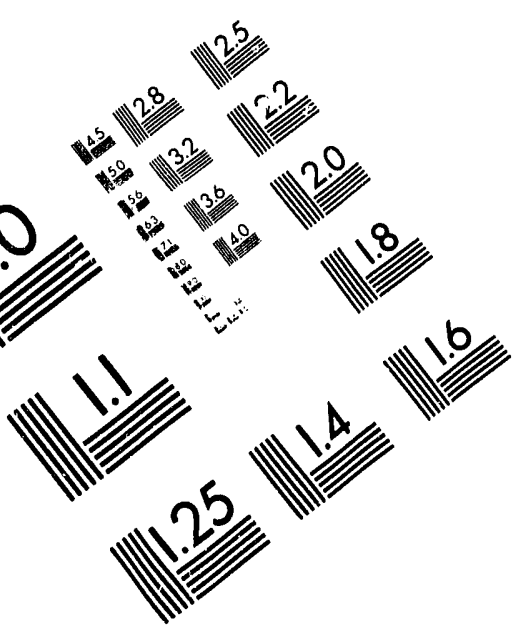

Association for Information and Image Management

1100 Wayne Avenue, Suite 1100

Silver Spring, Maryland $2091 \mathrm{C}$

301/587-8202

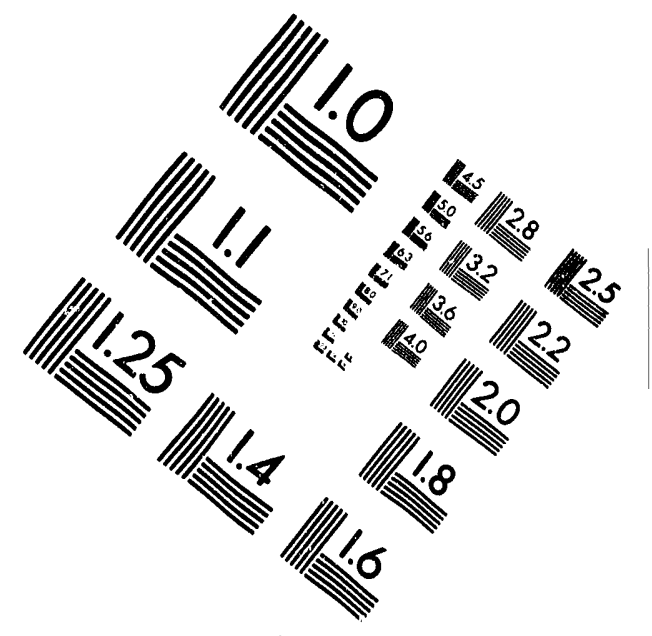

\title{
Centimeter
}

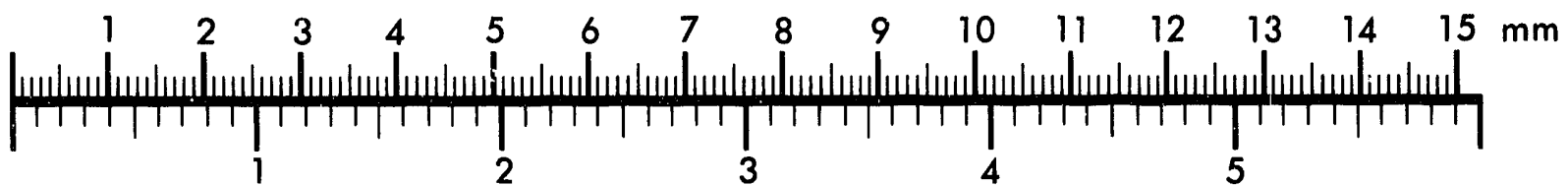
Inches
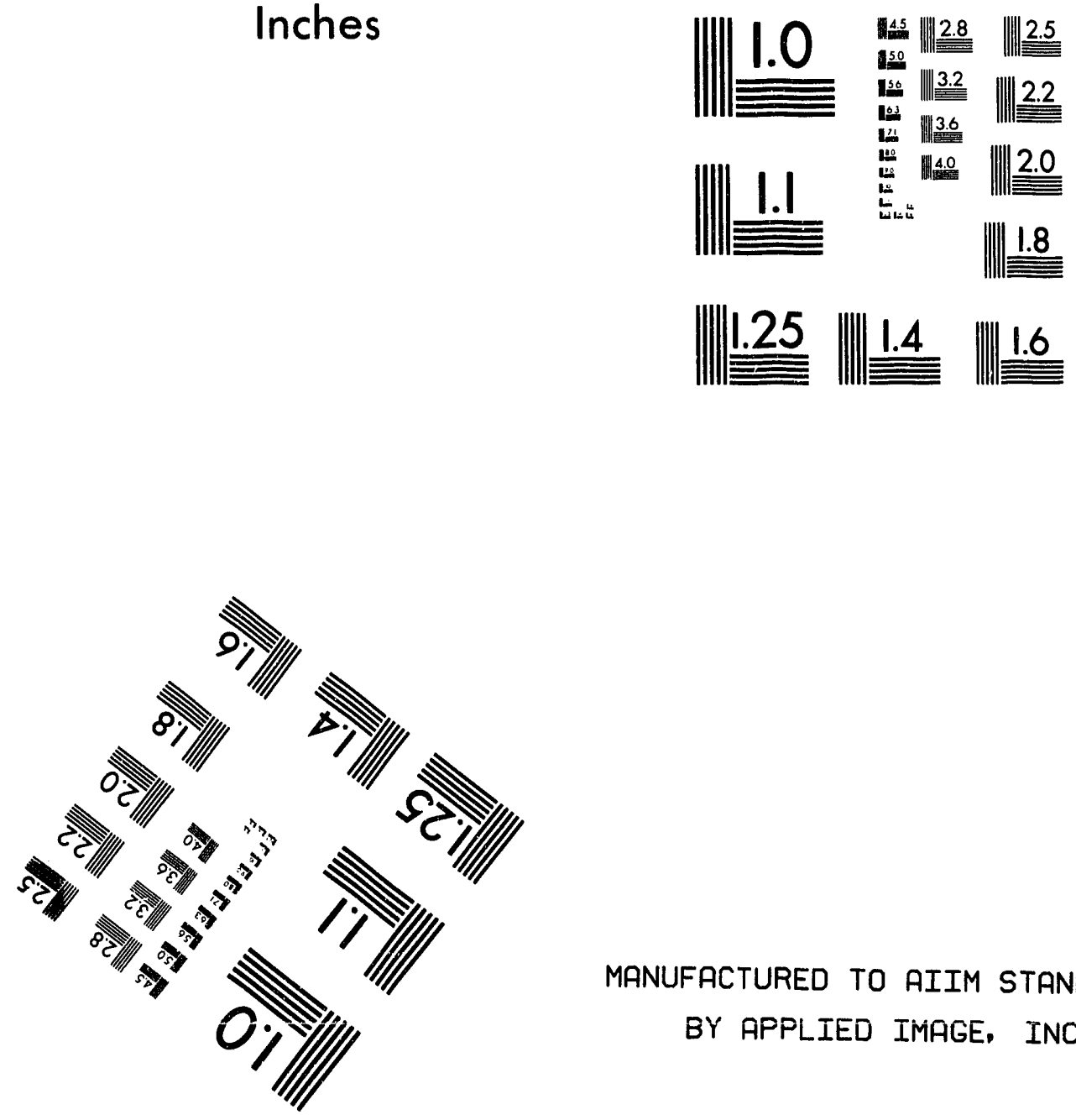

MANUFACTURED TO AIIM STANDARDS BY APPLIED IMAGE, INC.

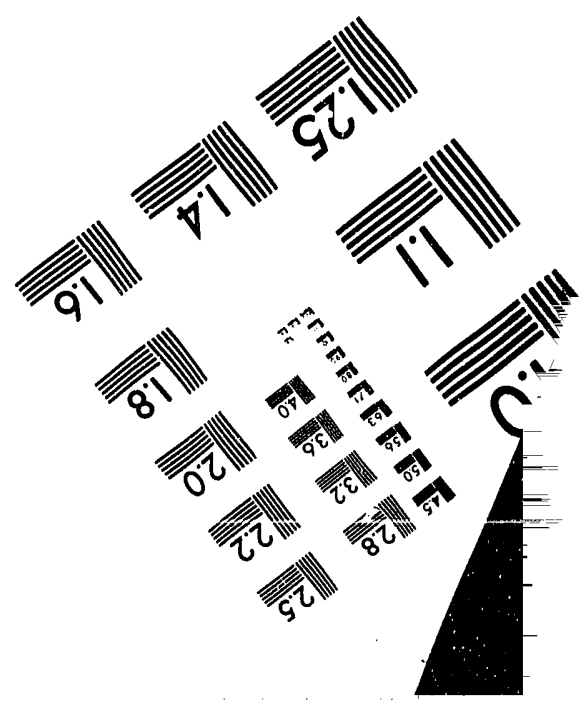



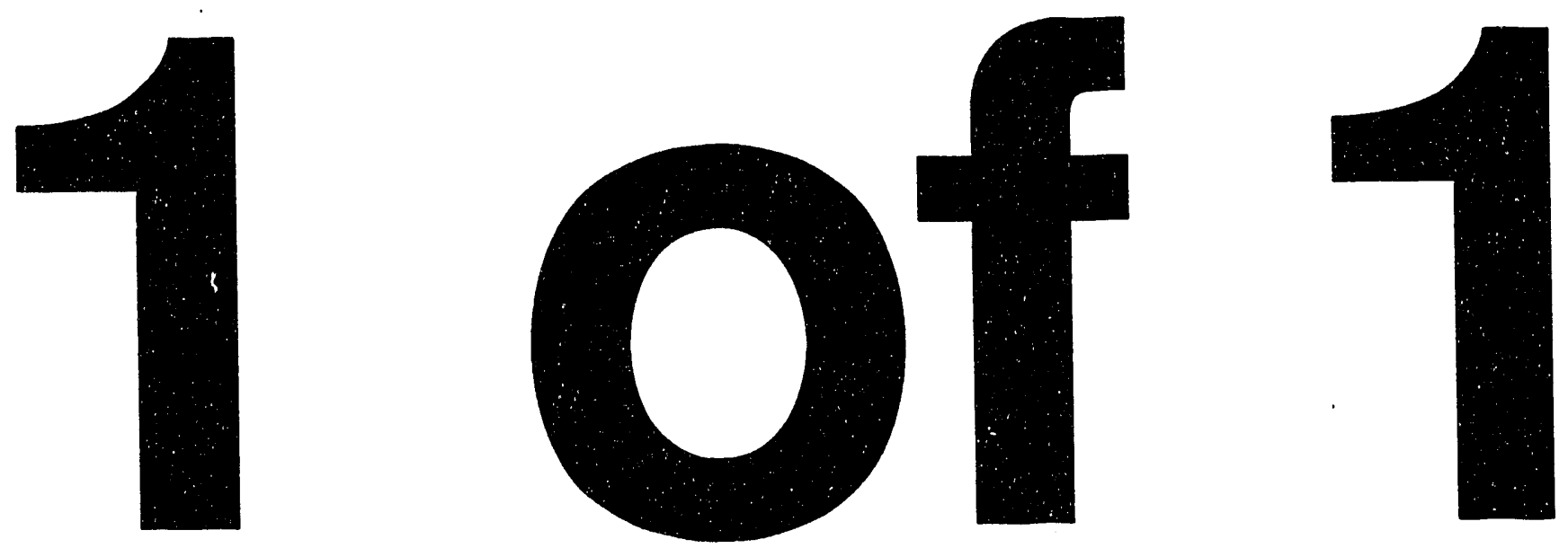


\section{Hanford Site Treated Effluent Disposal Facility Process Flow Sheet}

R. B. Bendixsen

Date Published

April 1993

To Be Presented at Americ an Nuclear Society 1993 Annual Meeting San Diego, California July 20-24, 1993

Prepared for the U.S. Department of Energy Assistant Secretary for Nuclear Energy

\begin{tabular}{ll} 
Westinghouse & P.O. Box 1970 \\
\hline
\end{tabular}

Hanlord Operations and Engineering Contractor for the U.S. Department of Energy under Contract DE-AC06-87RL10930

Copyright Licenses By acceptance of this aricta, the publisher and/or rocipiont acknowledges the U.S. Government's right to rolain a nonuxclusive, coyaly. treo license in and to any copyright oovering this paper.

\section{MASTER}

Approved for Public Release 
WHC - SA - 1751-FP

TREATED EFFLUENT DISPOSAL FACILITY FLOW SHEET

\section{INTRODOCTION}

This report presents a novel method of using precipitation, destruction and recycle factors to prepare a process flow sheet. The 300 Area Treated Effluent Disposal Facility (TEDF) will treat process sewer waste water from the 300 Area of the Hanford Site, located near Richland, Washington, and discharge a permittable effluent flow into the Columbia River. When completed and operating, the TEDF effluent water flow will meet or exceed water quality standards for the 300 Area process sewer effluents. A preliminary safety analysis document (PSAD), a preconstruction requirement, needed a process flow sheet detailing the concentrations of radionuclides, inorganics and organics throughout the process, including the effluents.

A PSAD usually includes a flow sheet, a requirement of Regulatory Guide 3.26 (NRC 1975), showing "the process, materials and heat balances and instrumentation." The flow sheet should provide estimates of stream flow quantities, activities, compositions, and properties; (i.e. temperature, pressure, specific gravity, $\mathrm{pH}$ and heat transfer rates). Preparing a flow sheet with all of the information for the components was necessary to complete the safety document.

Previous flow sheets did not provide detailed information for each flow stream of the concentrations of radionuclide, inorganic and organic components. For radionuclide, inorganic and organic components, precipitation factors, destruction factors, and two recycle factors were needed to estimate stream flow quantities for the TEDF. The factors could then be entered on a computer spread sheet and equations would estimate the steady state concentrations of all of the components in the facility. The factors would also provide a convenient method for improving the accuracy of the flow sheet as the facility begins to operate and the factors reflect operating data.

As the facility begins to operate, data from process samples can be used to provide better estimates of the factors, the factors can be entered into the flow sheet and the flow sheet will estimate more accurate steady state concentrations for the components. This report shows how the factors were developed and how they were used in developing a flow sheet to estimate component concentrations for the process flows. The report will conclude with how TEDF sample data can improve the ability of the flow sheet to accurately predict concentrations of components in the process.

\section{METHODOLOGY}

The TEDF, to be operated by Westinghouse Hanford Company near Richland, Washington, will use best available technology to treat the process sewer waste water flow. Figure 1 shows a simplified schematic of the TEDF process flow streams. The process will use ironcoprecipitation, filtration, ion exchange, ultraviolet-hydrogen peroxide (UV/ $\mathrm{H}_{2} \mathrm{O}_{2}$ ) destruction and sludge separation technology to further reduce low concentrations of heavy metals, suspended solids, organic compounds, and cyanide. Figure 1 shows a simplified schematic of the TEDF process. The TEDF building contains the main process components of the treatment system: tanks, pumps, ion exchange columns, a filter press, filter units, $\mathrm{UV} / \mathrm{H}_{2} \mathrm{O}_{2}$ units, the control room, men and women change rooms, a lunchroom and the electrical distribution equipment. The clarifier tanks, chemical supply storage tanks, diversion tanks and equalization feed tank are located outside of and adjacent to the TEDF building. 
Preparation.$:$ the TEDF flow sheet included using a computer spread sheet. During steady state operation, the TEDF flow sheet has four recycle flows (sludge, filter backwash, ion exchange backwash, and filter press filtrate) within the process. The recycle flows presented a challenge for the computer spread sheet because the circular reference of formulas "circ" status indicator will be lighted during spread sheet preparation if the calculations for 2 or more spread sheet cells are dependant on each other. The requirement for noncircular dependent equations was the driving force for developing "factors" to estimate concentrations of components in the recycle flows. The development of factors for the precipitation, filter, ion exchange and $\mathrm{UV} / \mathrm{H}_{2} \mathrm{O}_{2}$ processing operations provided the "novel approach" for developing noncircular equations.

The precipitation factor means the fraction of the influent component that precipitates and exits with the effluent sludge flow. The $\mathrm{UV} / \mathrm{H}_{2} \mathrm{O}_{2}$ fractor means the fraction of the influent component destructed by the $\mathrm{UV} / \mathrm{H}_{2} \mathrm{O}_{2}$ units. The filter and ion exchange factors estimate the fraction of the influent component captured by the respective filter units and ion exchange units and recycled during backwash operations of the filter and ion exchange units.

During steady state operations, the TEDF process continuously receives feed from the drain collection sump through the equalization feed tank, heavy metal components precipitate in the clarifiers, the filter units remove residual solids carry over from the clarifiers, the ion exchange columns remove mercury by adsorption on ion specific resins and the $\mathrm{UV} / \mathrm{H}_{2} \mathrm{O}_{2}$ units destruct organic and cyanide compounds. Steady state operation depicts a relationship (set of equations) between the influent, effluents and recycle liquid flows that is both predictable and measurable. Therefore, the factors provide the means to avoid circular equations and, using other process assumption factors, estimate steady state liquid concentrations and flow quantities for the 28 flows in the process.

Laboratory experiments using synthetic and actual process sewer liquids and data from similar operating facilities provided the means to estimate the initial "factors" for the radionuclide, inorganic, and organic components. Where sample data is lacking, conservative factors using engineering judgement were used. In the laboratory, ferric chloride, sodium hydroxide, and a high-molecular-weight anionic polymer added to solutions simulating TEDF feed flows provided data of the concentrations in the supernate and sludge after settling of the solids. Dividing the sludge concentration by the initial solution concentration gives the precipitation factor for each component. Similar applications using the ferric chloride precipitation process suggest that a recycle rate of $20 \mathrm{~kg}$ of sludge solids per $\mathrm{kg}$ of new solids formed in the feed 
Figure 1. Simplified Schematic of the 300 Area

Treated Effluent Disposal Facility.

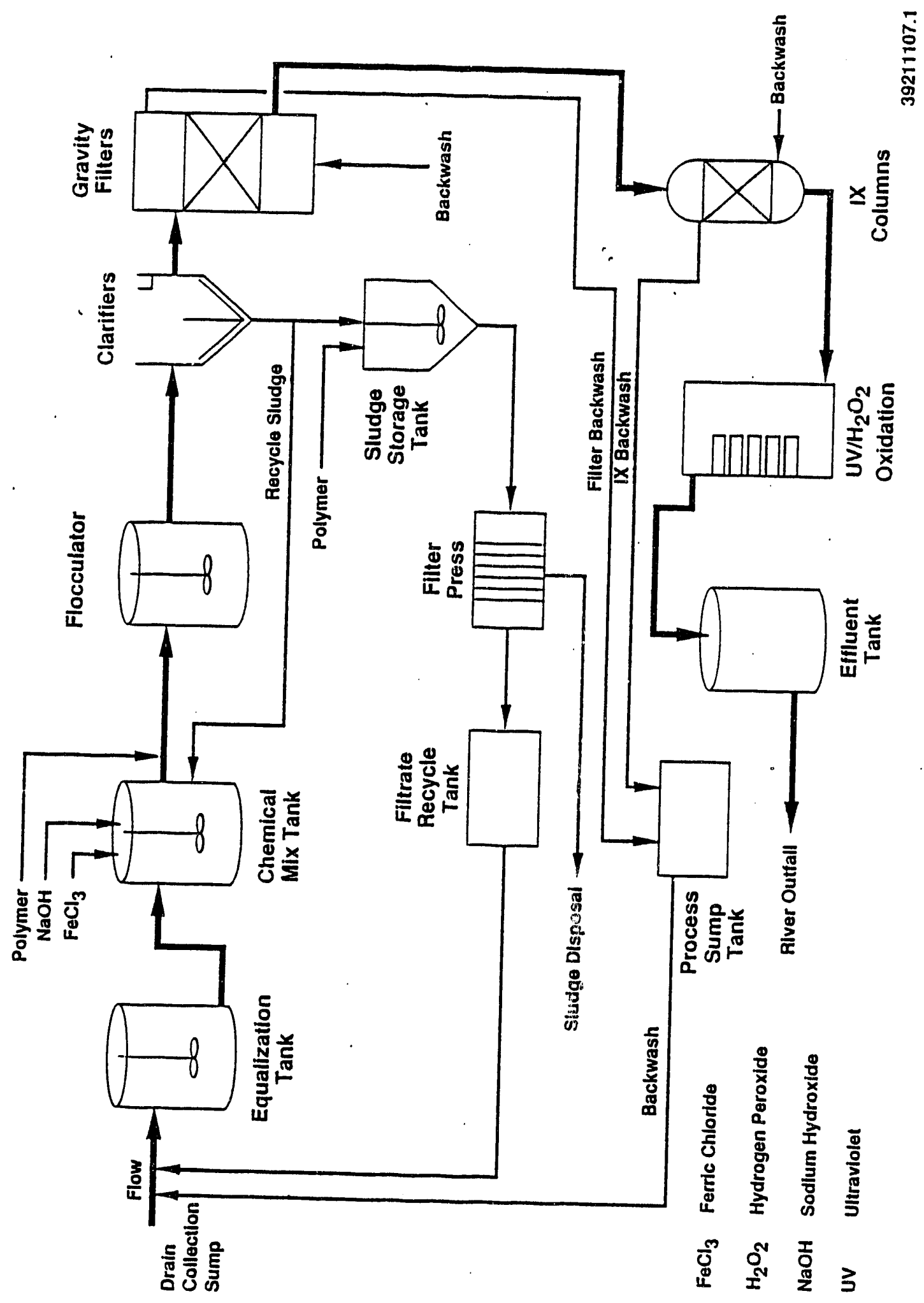


flow enhances metals removal and sludge settleability. Similarly, laboratory data from ion exchange column mexcury removal simulation, simulated filtration and organic destruction using ultraviolet light with hydrogen peroxide additions provided estimates of the factors for these unit processes.

Equations in the spread sheet, placed in the spread sheet to estimate concentrations for the flows in the TEDF process, use the factors, data from similar applications and process assumptions to calculate the steady state concentrations. Figure 2 shows an example calculation for estimating ${ }^{90} \mathrm{Sr}$ flow quantity in liquid flow from the clarifiers to the filters (Flow 非). The example demonstrates the use of factors and process flow assumptions. The quantity in Flow 非 5 includes unprecipitated ${ }^{90} \mathrm{Sr}$, a filter backwash quantity, an ion exchange backwash quantity, a backwash solution quantity, and minus a quantity contained in the solution mixed with the sludge effluent. Values for the quantities are also shown in Figure 2. This example uses three factors to estimate the flow quantity in the clarifier overflow: the precipitation factor, the filter backwash factor, and the IX backwash factor.

Figure 3 shows a sample calculation for estimating the destruction and effluent flow quantity $(4,300 \mu \mathrm{g} / \mathrm{min})$ of acetone within the $\mathrm{UV} / \mathrm{H}_{2} \mathrm{O}_{2}$ Oxidation units. The flow sheet contains equations for calculating the quantity of hydrogen peroxide added to the flow entering the $\mathrm{UV} / \mathrm{H}_{2} \mathrm{O}_{2}$. The reaction equation (Figure 3) shows that 8 moles of hydrogen peroxide are needed for every mole of acetone and the reaction yields 3 moles of carbon dioxide and 11 moles of water. The flow sheet contains reaction equation information for all of the organics including the inorganics $\left(\mathrm{CN}^{-}, \mathrm{NO}_{2}^{-}\right.$, and $\mathrm{S}^{-}$), which are oxidized in the $\mathrm{WV} / \mathrm{H}_{2} \mathrm{O}_{2}$ oxidation units. The byproducts of acetone oxidation are carbon dioxide and water. Carbon dioxide leaves the solution as a gas while the water from the reaction remains in the solution. The oxidation of some organics produces other ions $\left(\mathrm{NO}_{3}{ }^{-}, \mathrm{Cl}^{-}, \mathrm{F}^{-}\right.$ and $\mathrm{SO}_{4}$ ), which remain in solution and flow with the effluent flow to the river.

\section{RESULTS}

The fully developed flow sheet for the TEDF contains factors for 15 radionuclides, 42 inorganics and 22 organic compounds. The spread sheet containing the flow sheet includes all of the flow values, the equations and the factors for 28 flows. Tables 1 and 2 display a sampling of the factors and concentrations for the primary radionuclide, inorganic and organic compounds. For example, a feed concentration for ${ }^{137} \mathrm{Cs}$ of $46 \mathrm{pCi} / \mathrm{L}$ results in a waste water effluent flow concentration of $45.5 \mathrm{pCi} / \mathrm{L}$ and a sludge concentration of $897 \mathrm{pCi} / \mathrm{L}$.

Using a spread sheet for the process flow sheet benefits many groups other than the process engineering group. Other organizations can use the spread sheet by replacing the feed stream values with different values. The spread sheet responds by estimating new concentration values based on the new feed values. Changing the spread sheet values for the factors also changes the concentration values. The safety analysis group can use the flow sheet to estimate concentrations when accident or bounding source term values replace the feed values. Advanced engineering groups can use the spread sheet to predict the effects of changing the factors or for parametric studies involving a variety of feed stream concentration changes. Health Physics groups can use the spread sheet to estimate effluent stream concentrations 
WHC - SA - 1751- F]?

Figure 2. Sample Calculations for the Clarifier Effluent Flow (Flow $\left.\right|^{5} 5$ )

Flow \#5 - Unprecipitated 1,230 pCi/min * (1-.25a)$$
{ }^{90} \mathrm{Sr}
$$

$\mathrm{pCi} / \mathrm{min}$

$+923$

- Product Sludge Loss $923 \mathrm{pCi} / \mathrm{min} *(.482 / 1363)$

$-.3$

+ Filter Recycle $1230 \mathrm{pCi} / \mathrm{min} * .02^{\mathrm{b}}$

24.6

+ IX Recycle $1230 \mathrm{pCi} / \mathrm{min} * .0001^{\circ}$

.1

+ Solution Recycle

$\underline{42.6}$

Flow 非 ${ }^{90} \mathrm{Sr}$

$990 \mathrm{pCi} / \mathrm{min}$

Precipitation factor

bFilter backflush factor

'IX backflush factor 
Figure 3. Sample Calculation

Acetone Destruction in the $\mathrm{UV} / \mathrm{H}_{2} \mathrm{O}_{2}$ Oxidation Unit

Quantity in Flow 18 , Flow into the $\mathrm{UV} / \mathrm{H}_{2} \mathrm{O}_{2}$ Oxidation Unit

\begin{tabular}{|c|c|c|c|c|}
\hline \multicolumn{3}{|c|}{$\begin{array}{cc}\text { Unprecipitated } & \text { Sludge Loss } \\
86,100 & 41.7\end{array}$} & $\begin{array}{c}\text { - IX Adsorbed Loss } \\
0\end{array}$ & $\begin{array}{c}\text { Flow 非 } \\
-\quad 86,060 \mu \mathrm{g} / \mathrm{min}\end{array}$ \\
\hline \multicolumn{3}{|c|}{$\begin{array}{l}\mathrm{UV} / \mathrm{H}_{2} \mathrm{O}_{2} \text { Destruction } \\
86,060 \mu \mathrm{g} / \mathrm{min} *\left(1-.95^{\mathrm{a}}\right)=\end{array}$} & \multicolumn{2}{|c|}{$\begin{array}{c}\text { Quantity in Effluent } \\
4,300 \mu \mathrm{g} / \mathrm{min}\end{array}$} \\
\hline \multicolumn{5}{|c|}{ Acetone Destruction Reaction } \\
\hline $\begin{array}{l}\text { Ace tone } \\
\mathrm{C}_{3} \mathrm{H}_{6} \mathrm{O}\end{array}$ & + & $\begin{array}{l}\text { Hydrogen Peroxide } \\
\qquad 8 \mathrm{H}_{2} \mathrm{O}_{2}\end{array}$ & $\begin{array}{l}\text { Carbon Dioxide } \\
3 \mathrm{CO}_{2}+\end{array}$ & $\begin{array}{l}\text { Water } \\
11 \mathrm{H}_{2} \mathrm{O}\end{array}$ \\
\hline $\begin{array}{l}\mathrm{a} \\
\mathrm{UV} \\
\mathrm{H}_{2} \mathrm{O}_{2}\end{array}$ & & $\begin{array}{l}\text { Acetone destruction fa } \\
\text { Ultraviolet } \\
\text { Hydrogen peroxide }\end{array}$ & ctor & \\
\hline
\end{tabular}


WHC-SA-1751-FP

\begin{tabular}{|c|c|c|c|c|}
\hline \multicolumn{5}{|c|}{$\begin{array}{l}\text { Table 1. Typical Factors for Radionuclides } \\
\text { Inorganic and Organic Compounds }\end{array}$} \\
\hline Description & $\begin{array}{l}\text { Precipitation } \\
\text { Factor }\end{array}$ & $\begin{array}{l}\text { Filter } \\
\text { Backwash } \\
\text { Factor }\end{array}$ & $\begin{array}{l}\text { Ion Exchange } \\
\text { Backwash } \\
\text { Factor }\end{array}$ & $\begin{array}{l}\mathrm{UV} / \mathrm{H}_{2} \mathrm{O}_{2} \\
\text { Destruction } \\
\text { Factor }\end{array}$ \\
\hline \multicolumn{5}{|c|}{ Radionuclides } \\
\hline${ }^{90} \mathrm{Sr}$ & .25 & .02 & .0001 & 0 \\
\hline${ }^{137} \mathrm{Cs}$ & .01 & .02 & .01 & 0 \\
\hline${ }^{147} \mathrm{Pm}$ & .01 & .02 & .01 & 0 \\
\hline${ }^{241} \mathrm{Am}$ & .95 & .02 & .01 & 0 \\
\hline \multicolumn{5}{|c|}{ Inorganics } \\
\hline Al & .95 & .02 & .01 & 0 \\
\hline $\mathrm{CN}^{-}$ & .95 & .02 & .01 & .49 \\
\hline$\therefore \mathrm{Hg}$ & .05 & .02 & .01 & .949 \\
\hline $\mathrm{Zn}$ & .95 & .02 & .01 & 0 \\
\hline \multicolumn{5}{|c|}{ Organics } \\
\hline $\begin{array}{l}\text { Bis (ethyl- } \\
\text { hexyl)phthalate }\end{array}$ & 0 & .05 & .05 & .963 \\
\hline $\begin{array}{c}\text { Chlorodifluoro } \\
\text { methane }\end{array}$ & 0 & .05 & .05 & .95 \\
\hline $\begin{array}{l}\text { Methylene } \\
\text { Chloride }\end{array}$ & 0 & .05 & .05 & .95 \\
\hline
\end{tabular}


WHC - SA - 1751-FP

\begin{tabular}{|c|c|c|c|c|}
\hline Description & Units & $\begin{array}{l}\text { Feed to the } \\
\text { TEDF }\end{array}$ & $\begin{array}{c}\text { TEDF } \\
\text { Effluent to } \\
\text { the River }\end{array}$ & $\begin{array}{c}\text { TEDF } \\
\text { Sludge } \\
\text { Effluent } \\
\end{array}$ \\
\hline Form & & Iiquid & Liquid & Semi-Liquid \\
\hline Flow & L/min & 1230 & 1230 & .653 \\
\hline Temperature & ${ }^{\circ} \mathrm{C}$ & 10 & 13.2 & 23 \\
\hline \multirow[t]{2}{*}{$\begin{array}{l}\text { Specific } \\
\text { Gravity }\end{array}$} & $g / c c$ & 1.0 & 1.0 & 1.03 \\
\hline & & \multicolumn{2}{|l|}{ Radionuclides } & \\
\hline${ }^{90} \mathrm{Sr}$ & $\mathrm{pCi} / \mathrm{L}$ & 1.0 & .749 & 47.1 \\
\hline${ }^{137} \mathrm{Cs}$ & $\mathrm{pCi} / \mathrm{L}$ & 46 & 45.5 & 897 \\
\hline${ }^{147} \mathrm{Pm}$ & $\mathrm{pCi} / \mathrm{L}$ & 9 & 8.9 & 175 \\
\hline${ }^{241} \mathrm{Am}$ & $\mathrm{pCi} / \mathrm{L}$ & .6 & .03 & 1,070 \\
\hline \multicolumn{5}{|c|}{ Inorganics } \\
\hline$\Lambda 1$ & $\mu \mathrm{g} / \mathrm{L}$ & 418 & 20.9 & 74,800 \\
\hline $\mathrm{CN}^{-}$ & $\mu \mathrm{g} / \mathrm{L}$ & 50 & 2.37 & 89,400 \\
\hline $\mathrm{Hg}$ & $\mu \mathrm{g} / \mathrm{L}$ & 3 & .003 & 284 \\
\hline $\mathrm{zn}$ & $\mu \mathrm{g} / \mathrm{L}$ & 211 & 10.5 & 378,000 \\
\hline \multicolumn{5}{|c|}{ Organics } \\
\hline $\begin{array}{c}\text { Bis (ethyl } \\
\text { hexy 1)pthalate }\end{array}$ & $\mu \mathrm{g} / \mathrm{L}$ & 80 & 2.96 & 53.4 \\
\hline $\begin{array}{c}\text { Chlorodifluoro } \\
\text { methane }\end{array}$ & $\mu \mathrm{g} / \mathrm{L}$ & 20 & .999 & 13.3 \\
\hline $\begin{array}{c}\text { Methylene } \\
\text { Chloride }\end{array}$ & $\mu g / L$ & 5.1 & .255 & 3.4 \\
\hline
\end{tabular}

TEDF-300 Area Treated Effluent Disposal Facility. 
when plant conditions change. In addition, process engineering can study the effect of changing parameters for both current and future equipment configurations on the product and effluent values.

The spread sheet allows process engineering to predict process performance and to improve estimates as better sampling data becomes available. When estimated values are different than sample results, changing the factors will make the spread sheet a more accurate estimating tool for the process. Also, laboratory analysis of new specie allows process engineering to update the spread sheet by inserting the new compounds along with estimates of the factors, molecular weight, and destruction products if the new compound reacts in the $\mathrm{UV} / \mathrm{H}_{2} \mathrm{O}_{2}$ Oxidation unit. Thus, the spread sheet becomes a better tool as more data becomes available on the process.

In conclusion, a computer spread sheet for the TEDF uses factors based on feed concentrations to estimate stream concentrations for radionuclide, inorganic and organic compounds. The factors are an improved method for estimating flow concentrations in the TEDF process. The process flow sheet satisfies the requirements for the safety analysis document. The computer spread sheet contains the flow values, equations and factors. This spread sheet can be used by many groups to study the effluent treatment process. The spread sheet can be updated as better sample analysis of the flow concentrations become available.

\section{REFERENCES}

NRC, 1975, Standard Format and Content of Safety Analysis Reports for Fuel Processing Plants, Regulatory Guide 3.26, U.S. Nuclear Regulatory Commission, Washington, D.C. 

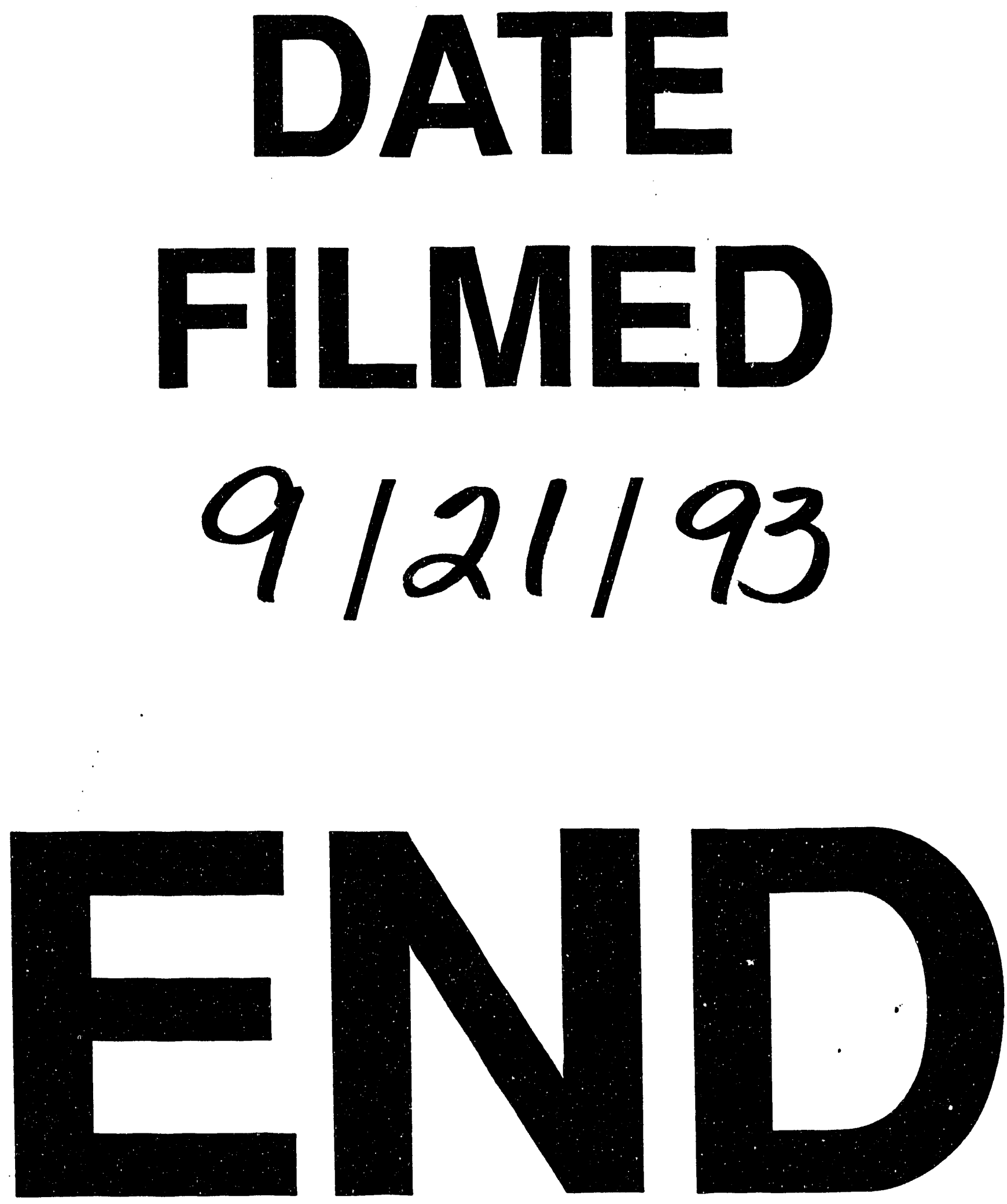